\author{
Dorota MilanowsKa ${ }^{1}$
}

\title{
Płatność za zazielenienie w nowym modelu dopłat bezpośrednich
}

\section{Wspólna polityka rolna a polityka ochrony środowiska naturalnego}

Współzależność polityki rolnej i polityki ochrony środowiska odzwierciedla katalog instrumentów wspólnej polityki rolnej Unii Europejskiej (WPR). Po raz pierwszy płatność rolnośrodowiskową wprowadzono w II filarze WPR; art. 39 rozporządzenia (WE) nr 1698/2005² dotyczącego wsparcia rozwoju obszarów wiejskich w okresie programowania 2007-2013 (w obecnym okresie programowania 20142020: art. 28 rozporządzenia (UE) $\mathrm{nr}$ 1305/201333) zobowiązywał państwa członkowskie do włączenia tego rodzaju płatności do krajowych programów wspierania rozwoju obszarów wiejskich. Płatność rolnośrodowiskowa w II filarze WPR przyznawana jest rolnikom dobrowolnie podejmującym zobowiązania rolnośrodowiskowe, czyli w rzeczywistości ma charakter fakultatywny, a korzystne oddziaływanie na środowisko naturalne stosowanych praktyk ograniczone jest do gruntów rolnych rolników chcących skorzystać z tego rodzaju pomocy.

W 2004 r. elementy środowiskowe zostały także włączone do WRP poprzez wymogi zasady wzajemnej zgodności (cross compliance), zgodnie z którą rolnicy otrzymujący płatności w ramach systemów wsparcia bezpośredniego oraz w ramach programu wspierania rozwoju obszarów wiejskich są zobowiązani do przestrzegania wymogów w zakresie zarządzania i utrzymania gruntów w dobrej kulturze rolnej, wynikających z odpowiednich przepisów sektorowego prawodawstwa rolnego. ${ }^{4}$

$1 \quad$ Autorka jest pracownikiem Komisji Europejskiej. Poglądy wyrażone w artykule są wyłącznie poglądami autorki i nie wiążą Komisji Europejskiej.

2 Rozporządzenie Rady (WE) nr 1698/2005 z dnia 20 września 2005 r. w sprawie wsparcia rozwoju obszarów wiejskich przez Europejski Fundusz Rolny na rzecz Rozwoju Obszarów Wiejskich (EFRROW) (Dz.Urz. UE L 277, z dnia 21 października 2005 r., s. 1).

3 Rozporządzenie Parlamentu Europejskiego i Rady (UE) nr 1305/2013 z dnia 17 grudnia 2013 r. w sprawie wsparcia rozwoju obszarów wiejskich przez Europejski Fundusz Rolny na rzecz Rozwoju Obszarów Wiejskich (EFRROW) i uchylające rozporządzenie Rady (WE) nr 1698/2005 (Dz.Urz. UE L 347 z dnia 20 grudnia 2013 r., s. 487). 2003 r. ustanawiającym wspólne zasady dla systemów wsparcia bezpośredniego w ramach wspólnej polity- 
W trakcie reformy „ocena funkcjonowania” z 2008 r. podkreślono, że instrumenty WPR odgrywają znaczącą rolę w zapobieganiu ryzyku związanemu z degradacją środowiska naturalnego. ${ }^{5}$ Konkretne rozwiązanie prawne zawarte zostało w rozporządzeniu Parlamentu Europejskiego i Rady (UE) nr 1307/2013 wprowadzającym płatność z tytułu praktyk rolniczych korzystnych dla klimatu i środowiska, która, począwszy od 1 stycznia 2015 r., jest obowiązkowym elementem płatności bezpośrednich uzależnionym od przestrzegania przez rolnika przepisanych prawem praktyk rolniczych korzystnych dla środowiska i klimatu. ${ }^{6}$ Włączenie komponentu ekologicznego do I filara WPR ma umożliwić jednolite stosowanie praktyk środowiskowych w całej Unii. ${ }^{7} \mathrm{~W}$ odniesieniu do terminologii należy nadmienić, że „płatność za zazielenienie” jest terminem wprowadzonym przez ustawodawcę polskiego. ${ }^{8} \mathrm{~W}$ kontekście prac nad ostatnią reformą WPR stosowano również szersze znaczeniowo pojęcie ,zazielenienie” (ang. greening), odnoszące się do procesu włączania do systemu wsparcia bezpośredniego obligatoryjnego elementu związanego $\mathrm{z}$ ochroną środowiska.

\section{Charakter prawny płatności za zazielenienie}

Płatność bezpośrednia przysługująca rolnikowi w odniesieniu do wszystkich kwalifikujących się hektarów w rozumieniu art. 32 rozporządzenia (UE) nr 1307/2013 znajdujących się $\mathrm{w}$ posiadaniu rolnika składa się obecnie z płatności podstawowej (w przypadku Polski, w dalszym ciągu, jednolitej płatności obszarowej) oraz dopełniającej ją i uzależnionej od stosowania określonych praktyk rolniczych płatności za zazielenienie.

Płatność za zazielenienie jest płatnością roczną na kwalifikujący się zadeklarowany hektar. Na pokrycie płatności nie zostaną przeznaczone dodatkowe środki z budżetu Unii, a jej finansowanie będzie możliwe poprzez zmniejszenie odpowiedniej części płatności podstawowej dla danego rolnika. Oznacza to, że 30\% rocznego pułapu krajowego państw członkowskich będzie przeznaczone na finansowa-

ki rolnej i ustanawiającym określone systemy wsparcia dla rolników oraz zmieniającym rozporządzenia (EWG) nr 2019/93, (WE) nr 1452/2001, (WE) nr 1453/2001, (WE) nr 1454/2001, (WE) nr 1868/94, (WE) nr 1251/1999, (WE) nr 1254/1999, (WE) nr 1673/2000, (EWG) nr 2358/71 i (WE) nr 2529/2001 (Dz.Urz. UE L 270 z dnia 21 października 2003 r., s. 1).

$5 \quad$ Komunikat Komisji dla Rady i Parlamentu Europejskiego, Przygotowania do oceny funkcjonowania reformy WPR, COM (2007) 722, s. 2.

$6 \quad$ Por. uzasadnienie wprowadzenia płatności za zazielenienie zawarte w motywach (37) - (45) rozporządzenia Parlamentu Europejskiego i Rady (UE) nr 1307/2013 z dnia 17 grudnia 2013 r. ustanawiającego przepisy dotyczące płatności bezpośrednich dla rolników na podstawie systemów wsparcia w ramach wspólnej polityki rolnej oraz uchylającego rozporządzenie Rady (WE) nr 637/2008 i rozporządzenie Rady (WE) nr 73/2009 (Dz.Urz. UE L 347, z dnia 20 grudnia 2013 r., s. 608).

7 Szerzej na temat stopniowego włączania elementów ochrony środowiska naturalnego w ramy WPR zob. J. Martinez, Das Greening der Gemeinsamen Agrarpolitik, „Natur und Recht” (2013) 35, s. 690.

$8 \quad$ Zob. art. 2 pkt 7 ustawy $z$ dnia 5 lutego 2015 r. o płatnościach bezpośrednich w ramach systemów wsparcia bezpośredniego (Dz.U. z 2015 r., poz. 308). 
nie tej części płatności bezpośrednich, określanej jako ich komponent ekologiczny. ${ }^{9}$ Wypłata części dotychczasowej płatności przysługującej rolnikowi została zatem uzależniona od spełnienia określonych wymogów, naruszenie których będzie skutkowało nałożeniem kary administracyjnej w postaci zwrotu określonej części procentowej kwoty płatności za zazielenienie.

Rolnik ubiegający się o płatność podstawową jednocześnie musi ubiegać się o płatność za zazielenienie i deklaruje we wniosku spełnienie wymogów dotyczących stosowania przepisanych prawem praktyk rolniczych. Art. 22 rozporządzenia delegowanego Komisji (UE) nr 640/2014 ${ }^{10}$ mówi o ,zgłoszeniu” określonych gruntów. W praktyce polega to na zidentyfikowaniu we wniosku określonych obszarów gospodarstwa, których takie praktyki będą dotyczyły. Jedynie płatność za zazielenienie zależy od spełnienia wymogów związanych z ochroną środowiska, lecz rolnik składając wniosek o całość wsparcia ubiega się jednocześnie o tę płatność, więc de facto wypłata całości następuje, kiedy rolnik zobowiąże się do wypełnienia wymogów środowiskowych. ${ }^{11} \mathrm{~W}$ doktrynie prezentowane jest stanowisko, że mamy tu do czynienia ze swego rodzaju warunkiem sui generis otrzymania płatności w ramach wsparcia bezpośredniego. ${ }^{12} \mathrm{~W}$ literaturze przedmiotu warunek ten określa się także mianem „,kontrola prewencyjna”, ${ }^{13}$ która ma służyć skuteczniejszemu oddziaływaniu praktyk środowiskowych.

Trybunał Sprawiedliwości Unii Europejskiej nie wypowiedział się do tej pory na temat charakteru prawnego płatności za zazielenienie. Wyróżnikiem konstrukcji prawnej tej płatności jest element swoistej ,wymiany świadczeń”. ${ }^{14}$ Rolnik uzyskuje pomoc finansową w zamian za określone zachowanie, tzn. za stosowanie określonych praktyk rolniczych, których celem jest poprawa stanu środowiska naturalnego, czyli w zamian za określone zachowanie dla dobra społeczeństwa. Jest to element nowatorski w systemie dopłat bezpośrednich. W tym sensie konstrukcja płatności za zazielenienie może przypominać pomoc rolnośrodowiskową przyznawaną w ramach II filaru WPR. ${ }^{15}$

9 Por. art. 47 i załącznik II do rozporządzenia (UE) nr 1307/2013.

10 Rozporządzenie delegowane Komisji (UE) nr 640/2014 z dnia 11 marca 2014 r. uzupełniające rozporządzenie Parlamentu Europejskiego i Rady (UE) nr 1306/2013 w odniesieniu do zintegrowanego systemu zarządzania i kontroli oraz warunków odmowy lub wycofania płatności oraz do kar administracyjnych mających zastosowanie do płatności bezpośrednich, wsparcia rozwoju obszarów wiejskich oraz zasady wzajemnej zgodności (Dz.Urz. UE L 181 z dnia 20 czerwca 2014 r., s. 48).

11 Rolnik otrzymujący płatność podstawową musi jednak stosować się do wymogów zasady wzajemnej zgodności.

12 Zob. B. Schima, Der Vorschlag der Kommission für eine neue Direktzahlungsverordnung, [w:] Norer, Holzer (red.) Agrarrecht. Jahrbuch 2012, s. 141.

13 J. Martinez, Das Greening der Gemeinsamen Agrarpolitik, op. cit., s. 693.

14 Por. B. Mittermüller, Die Ökoprämie und ihre „eigentümliche” Rechtsnatur, [w:] Norer, Holzer (red.) Agrarrecht. op. cit., s. 170.

15 Por. motyw (22) rozporządzenia Parlamentu Europejskiego i Rady (UE) nr 1305/2013, w którym stwierdzono, że płatności rolnośrodowiskowo-klimatyczne poprzez stosowanie praktyk rolnych przyczyniających się do łagodzenia zmiany klimatu i do przystosowania się do niej, zgodnych z ochroną i poprawą stanu środowiska, krajobrazu i jego właściwości, zasobów naturalnych oraz gleby i różnorodności genetycznej mają służyć społeczeństwu i re- 
Wątpliwym jest, że ten rodzaj płatności może być określany jako płatność wspierająca dochód rolnika sensu stricto, którą są inne płatności obszarowe, w szczególności jednolita płatność obszarowa, mająca za główny cel wzrost dochodów z rolnictwa i poprawę warunków życia rolnika. ${ }^{16}$ Płatność za zazielenienie jako część płatności podstawowej pozostaje jednak roszczeniem publicznoprawnym. Spełniwszy wymogi odpowiednich przepisów prawa Unii i prawa krajowego oraz uzyskawszy decyzję administracyjną przyznającą pomoc i będącą źródłem prawa majątkowego, ${ }^{17} \mathrm{~W}$ tym płatności za zazielenienie, rolnikowi przysługuje roszczenie o wypłatę płatności. Płatność ta, podobnie jak inne płatności obszarowe, ma rodowód administracyjnoprawny i nie może być na gruncie prawa polskiego przedmiotem obrotu. ${ }^{18}$ Artykuły 26-28 obecnej ustawy o płatnościach bezpośrednich nie wprowadzają zmian w tym zakresie i szczegółowo regulują sytuacje, w których płatność przyznawana jest innemu podmiotowi niż podmiot składający wniosek (przekazanie gospodarstwa rolnego, śmierć wnioskodawcy, wystąpienie określonego prawem następstwa prawnego).

\section{Obowiązkowe praktyki rolnicze}

Otrzymanie płatności za zazielenienie zależy od spełnienia obowiązku stosowania trzech praktyk koniecznych z punktu widzenia ochrony środowiska albo tzw. praktyk równoważnych. Obowiązek ten wynika wprost z przepisów unijnych, czyli rozporządzenia (UE) nr 1307/2013, rozporządzenia delegowanego Komisji (UE) $\mathrm{nr} 639 / 2014{ }^{19}$ oraz rozporządzenia wykonawczego Komisji (UE) $\mathrm{nr} 641 / 2014 .{ }^{20}$ Do obowiązkowych praktyk rolniczych rozporządzenie (UE) nr 1307/2013 zalicza dywersyfikację upraw (art. 44), utrzymywanie istniejących trwałych użytków zielonych (TUZ) (art. 45) oraz utrzymywanie na użytkach rolnych obszaru proekologicznego (EFA) (art. 46).

A. Dywersyfikacja upraw polega na zapewnieniu przez rolnika występowania przynajmniej dwóch rodzajów upraw w przypadku, gdy grunty orne rolnika obejmują od 10 do 30 ha oraz 3 różnych upraw, gdy grunty orne zajmują więcej niż 30

kompensować koszty poniesione przez rolników wywiązujących się z podjętych zobowiązań na rzecz środowiska. 
ha. W obu przypadkach uprawa główna nie może zajmować więcej niż 75\% tych gruntów ornych, w przypadku drugim, jeśli występują dwie główne uprawy, nie mogą one zajmować więcej niż 95\% gruntów.

B. Obowiązek utrzymywania trwałych użytków zielonych polega na zaniechaniu przez rolnika przekształcania lub zaorywania trwałych użytków zielonych. W tym kontekście rozporządzenie nakłada na państwa członkowskie zadanie wcześniejszego wyznaczenia na ich terytoriach trwałych użytków jako wrażliwych pod względem środowiskowym na obszarach objętych zakresem dyrektyw 92/43/EWG (tzw. dyrektywa siedliskowa) ${ }^{21}$ i 2009/147/WE (tzw. dyrektywa ptasia). ${ }^{22}$ Państwa członkowskie mają też zapewnić, przez system kontroli, aby stosunek trwałych użytków zielonych do całej powierzchni użytków zadeklarowanych przez rolnika nie zmniejszył się o więcej niż 5\% w porównaniu do wskaźnika referencyjnego ustalonego przez państwa członkowskie w 2015 r. W przypadku przekroczenia tego progu państwa członkowskie mają obowiązek nałożenia na rolnika obowiązku w zakresie ponownego przekształcenia gruntu w trwałe użytki zielone.

C. Obowiązek wydzielenia obszarów proekologicznych dotyczy gospodarstw rolnych o powierzchni gruntów ornych przekraczającej 15 ha. Rolnicy posiadający takie gospodarstwa muszą zapewnić od 1 stycznia 2015 r., że przynajmniej 5\% gruntów ornych ich gospodarstwa zostało wydzielone jako obszary proekologiczne. Korelatem obowiązku rolnika jest obowiązek państwa członkowskiego zaliczenia określonych rodzajów obszarów do obszarów proekologicznych zgodnie z art. 46 ust. 2 rozporządzenia (UE) $\mathrm{nr}$ 1307/2013.

Pewne elementy dotyczące praktyk korzystnych dla środowiska zostały uszczegółowione w prawodawstwie krajowym. Przepisy prawa polskiego regulują określenie daty, do kiedy rolnik naruszający obowiązek utrzymania trwałych użytków zielonych musi ponownie przekształcić grunt w trwałe użytki zielone oraz kwestie proceduralne związane ze stwierdzeniem takiego obowiązku, kontrolą czy zastosowaniem postępowania egzekucyjnego w administracji. Przepisy krajowe określają także obszary uznane za obszary proekologiczne. ${ }^{23}$

D. Możliwość stosowania praktyk równoważnych jako ekwiwalentu trzech praktyk wprowadzonych przez prawo unijne wprowadza pewną elastyczność,

Dyrektywa Rady 92/43/EWG z dnia 21 maja 1992 r. w sprawie ochrony siedlisk przyrodniczych oraz dzikiej fauny i flory (Dz.Urz. WE L 206 z dnia 22 lipca 1992 r., s. 7).

22 Dyrektywa Parlamentu Europejskiego i Rady 2009/147/WE z dnia 30 listopada 2009 r. w sprawie ochrony dzikiego ptactwa (Dz.Urz. UE L 20 z dnia 26 stycznia 2010 r., s. 7).

23 Rozporządzenie Ministra Rolnictwa i Rozwoju Wsi z dnia 9 marca 2015 r. w sprawie wyznaczenia trwałych użytków zielonych wartościowych pod względem środowiskowym (Dz.U. z 2015 r. poz. 348); rozporządzenie Ministra Rolnictwa i Rozwoju Wsi z dnia 6 marca 2015 r. w sprawie okresu obliczania udziału różnych upraw w celu dywersyfikacji upraw (Dz.U. z 2015 r. poz. 340); rozporządzenie Ministra Rolnictwa i Rozwoju Wsi z dnia 11 marca 2015 r. w sprawie obszarów uznawanych za obszary proekologiczne oraz warunków wspólnej realizacji praktyki utrzymania tych obszarów (Dz.U. z 2015 r. poz. 354). 
zwłaszcza że katalog takich praktyk może być kształtowany przez państwa członkowskie także na poziomie regionów. ${ }^{24}$ Zgodnie z brzmieniem art. 43 ust. 3 rozporządzenia (UE) nr 1307/2013 praktyki równoważne to praktyki skutkujące równoważnym lub większym poziomem korzyści dla klimatu i środowiska w porównaniu do jednej lub kilku praktyk z trzech ww. praktyk obowiązkowych, wymienionych w jego załączniku IX. Rozporządzenie dzieli praktyki równoważne na trzy kategorie odpowiadające trzem głównym praktykom i zalicza do nich przykładowo odłogowanie, utrzymywanie przynajmniej czterech upraw, gospodarowanie bez używania nawozów.

\section{Podmioty zobowiązane do stosowania praktyk rolniczych korzystnych dla środowiska}

Zgodnie z art. 43 rozporządzenia (UE) nr 1307/2013 wymogi związane z płatnością za zazielenienie muszą spełniać rolnicy we wszystkich państwach członkowskich, niezależnie od tego, czy otrzymują płatności bezpośrednie w ramach systemu płatności podstawowej czy systemu jednolitej płatności obszarowej. Płatność za zazielenienie, podobnie jak inne płatności obszarowe, przysługuje jedynie rolnikom aktywnym zawodowo w rozumieniu przepisów rozporządzenia (UE) nr 1307/2013. Mowa tu o rolnikach: a) zaliczanych do rolników aktywnych zawodowo w rozumieniu art. $9 \mathrm{w}$ powiązaniu $\mathrm{z}$ art. 4(1)(a) tego rozporządzenia, czyli osobach fizycznych lub prawnych bądź grupie osób fizycznych lub prawnych, bez względu na status prawny takiej grupy i jej członków w świetle prawa krajowego, których gospodarstwo rolne jest położone na obszarze objętym zakresem terytorialnym Traktatów, określonym w art. 52 Traktatu o Unii Europejskiej w związku z art. 349 i 355 Traktatu o funkcjonowaniu Unii Europejskiej, oraz które prowadzą działalność rolniczą, oraz b) posiadających kwalifikujące się hektary w rozumieniu art. 32 ust. 2-5 rozporządzenia (UE) nr 1307/2013.

Działalność rolniczą rozporządzenie definiuje jako (i) produkcję, hodowlę lub uprawę produktów rolnych, w tym zbiory, dojenie, hodowlę zwierząt oraz utrzymywanie zwierząt do celów gospodarskich; (ii) utrzymywanie użytków rolnych w stanie, dzięki któremu nadają się one do wypasu lub uprawy bez konieczności podejmowania działań przygotowawczych wykraczających poza zwykłe metody rolnicze i zwykły sprzęt rolniczy, w oparciu o kryteria określone przez państwa członkowskie na podstawie ram ustanowionych przez Komisję, lub (iii) prowadzenie działań minimalnych, określanych przez państwa członkowskie, na użytkach rolnych utrzymujących się naturalnie w stanie nadającym się do wypasu lub uprawy. Sformułowanie w obecnym stanie prawnym definicji rolnika aktywnego zawodowo miało 
na celu wykluczenie z otrzymywania wsparcia bezpośredniego podmiotów posiadających grunty rolne, lecz nie mających rzeczywistych związków z rolnictwem.

Od jednolitego i ogólnego obowiązku stosowania praktyk środowiskowych na terenie całej Unii rozporządzenie (UE) nr 1307/2013 przewiduje dwa rodzaje wykluczeń: wykluczenie automatyczne oraz wykluczenie dotyczące stosowania jedynie wybranych praktyk. $Z$ jednej strony $\mathrm{z}$ wymogu stosowania praktyk na mocy art. 43 ust. 10 tego rozporządzenia zwolnione są podmioty prowadzące gospodarstwa ekologiczne; zwolnienie to dotyczy jednak wyłącznie jednostek gospodarstwa wykorzystywanych do produkcji ekologicznej zgodnie z przepisami rozporządzenia (WE) nr 843/2007. ${ }^{25} \mathrm{~W}$ przypadku takich producentów rolnych płatność za zazielenienie zostanie automatycznie dodana do kwoty otrzymywanej przez nich płatności podstawowej. U podstaw wykluczenia gospodarstw ekologicznych jest tzw. równoważność zazielenienia, polegająca na zwolnieniu z wymogów zazieleniania i niekaraniu gospodarstw, które stosują już praktyki zapewniające równoważny lub wyższy poziom ochrony środowiska.

Z drugiej strony wymogów zazieleniania muszą przestrzegać gospodarstwa rolne w całości lub części położone na obszarach objętych dyrektywami 92/43/ EWG (tzw. dyrektywa siedliskowa), 2000/60/WE (tzw. dyrektywa wodna) ${ }^{26}$ oraz 2009/147 (tzw. dyrektywa ptasia). Gospodarstwa takie otrzymają płatność za zazielenienie pod warunkiem, że przestrzegają praktyk zazielenienia $\mathrm{w}$ zakresie, $\mathrm{w}$ jakim praktyki te są $\mathrm{w}$ danym gospodarstwie rolnym zgodne $\mathrm{z}$ celami wymienionych wyżej dyrektyw.

Artykuł 61 rozporządzenia (UE) nr 1307/2013 przewiduje zwolnienie z obowiązku stosowania praktyk gospodarstw uczestniczących w systemie dla małych gospodarstw, stanowiąc, że płatności dla małych gospodarstw zastępują płatności, które mają zostać przyznane na podstawie tytułów III i IV tego rozporządzenia (płatność podstawowa, płatność za zazielenienie, jednolita płatność obszarowa, płatności powiązane, wsparcie związane z produkcją). Ustawodawca polski udostępnił system dla małych gospodarstw wszystkim gospodarstwom, których kwota roczna płatności bezpośrednich nie przekracza 1250 euro. ${ }^{27}$

Pozostałe zwolnienia dotyczą stosowania określonych praktyk zazielenienia. Art. 44 ust. 3 i art. 46 ust. 4 rozporządzenia (UE) nr 1307/2013 zwalniają z obowiązku prowadzenia praktyki dywersyfikacji upraw i zachowania obszarów proekologicznych przykładowo gospodarstwa rolne, w których więcej niż 75\% gruntów

25 Rozporządzenie Rady (WE) nr 834/2007 z dnia 28 czerwca 2007 r. w sprawie produkcji ekologicznej i znakowania produktów ekologicznych i uchylające rozporządzenie (EWG) nr 2092/91 (Dz.Urz. UE L 189 z dnia 20 lipca 2007 r., s. 1).

26 Dyrektywa 2000/60/WE Parlamentu Europejskiego i Rady z dnia 23 października 2000 r. ustanawiająca ramy wspólnotowego działania w dziedzinie polityki wodnej (Dz.Urz. WE L 327 z dnia 22 grudnia 2000 r., s. 1). Zob. art. 19 ust. 2 ustawy o płatnościach w ramach systemów wsparcia bezpośredniego. 
ornych jest wykorzystywane do produkcji traw lub innych pastewnych roślin zielonych, jest ugorowane lub jest połączeniem tych zastosowań, pod warunkiem, że pozostałe grunty orne nie przekraczają 30 hektarów. Jeżeli więcej niż $75 \%$ kwalifikujących się użytków rolnych stanowią trwałe użytki zielone, rolnika nie obejmuje ani praktyka dywersyfikacji, ani obowiązek utrzymywania obszaru proekologicznego, pod warunkiem, że pozostałe grunty orne nie przekraczają 30 hektarów. Ponadto $\mathrm{z}$ obowiązku dywersyfikacji zwolnione są na mocy art. 44 ust. 1 rozporządzenia (UE) nr 1307/2013 grunty orne rolnika, jeśli obejmują one mniej niż 10 ha. Na mocy art. 46 ust. 1 rozporządzenia (UE) nr 1307/2013 obowiązek utrzymywania obszaru proekologicznego nie obejmuje natomiast gruntów ornych, jeśli ich powierzchnia nie przekracza 15 ha.

Z przytoczonych regulacji prawnych wynika, że pomimo szerokiego zasięgu praktyk środowiskowych, które z założenia miały być stosowane jednolicie i obowiązywać wszystkich rolników uprawnionych do płatności obszarowych, ich skuteczność może ograniczać przedstawiony system zwolnień. O ile automatyczne wyłączenie gospodarstw prowadzących produkcję ekologiczną jest zrozumiałe ze względu na stosowanie przez te gospodarstwa praktyk korzystnych dla środowiska, o tyle zdziwienie może budzić regulacja wyłączająca $\mathrm{z}$ obowiązku zazieleniania gospodarstwa uczestniczące w systemie dla małych gospodarstw. Zastosowanie tego wyjątku spowoduje, że w Polsce zwolnieniem zostanie objętych ok. 68 tys. gospodarstw. Do takich gospodarstw nie będą też miały zastosowania wymogi związane z zasadą wzajemnej zgodności, co stwierdza art. 92 rozporządzenia (UE) nr 1306/2013. Natomiast 83\% gospodarstw będzie zwolnione z obowiązku dywersyfikacji upraw, a $91 \%$ z obowiązku wydzielenia obszarów proekologicznych. ${ }^{28}$

\section{Zasada wzajemnej zgodności (cross-compliance) a płatność za zazielenienie}

Konsekwencją wprowadzenia od dnia 1 stycznia 2015 r. warunków związanych $\mathrm{z}$ płatnością za zazielenienie jest funkcjonowanie $\mathrm{w}$ ramach modelu dopłat bezpośrednich dwóch systemów dotyczących wymogów rolnośrodowiskowych: zasady wzajemnej zgodności oraz właśnie zazieleniania. Pracom ustawodawczym nad konstrukcją prawną zazieleniania towarzyszyło jednak założenie, że ten dodatkowy system ma wykraczać poza wymogi zasady wzajemnej zgodności, co potwierdza motyw (37) do rozporządzenia (UE) nr 1307/2013, w którym stwierdzono, że ,,[...] państwa członkowskie powinny przeznaczyć część pułapów krajowych dla płatności bezpośrednich, aby przyznawać, oprócz płatności podstawowej płatność roczną, która może uwzględniać wewnętrzne ujednolicenie w danym państwie członkow- 
skim lub regionie, $\mathrm{z}$ tytułu obowiązkowych praktyk rolniczych zgodnych z celami polityki dotyczącej zarówno klimatu, jak i środowiska. Praktyki te powinny polegać na prostych, ogólnych, pozaumownych i corocznych działaniach, które wykraczają poza zasadę wzajemnej zgodności i są związane z rolnictwem”.

Podstawowa różnica pomiędzy wymogami nałożonymi przez zasadę wzajemnej zgodności a wymogami zazieleniania polega na tym, że zasada wzajemnej zgodności wymaga od rolnika otrzymującego dopłaty bezpośrednie dopełnienia określonych obowiązków, lecz wynikających z innych dziedzin prawa i nie nakłada na rolnika żadnych nowych obowiązków. Jej celem jest wzmocnienie egzekwowania przepisów już obowiązujących. Jest to możliwe dzięki równoległości kontroli administracyjnych, które mogą być przeprowadzane przez same państwa członkowskie na podstawie odpowiednich przepisów sektorowego prawodawstwa rolnego oraz dodatkowych kontroli organizowanych przez Komisję w ramach zasady wzajemnej zgodności na podstawie przepisów rozdziału II rozporządzenia Parlamentu Europejskiego i Rady (UE) nr 1306/2013. ${ }^{29}$

Przepisy dotyczące zasady wzajemnej zgodności obejmują podstawowe wymogi w zakresie zarządzania (SMR) wynikające z prawa unijnego oraz normy utrzymania gruntów w dobrej kulturze rolnej zgodnej $\mathrm{z}$ ochroną środowiska (GAEC) z zakresu środowiska, zmiany klimatu, zdrowia publicznego, zdrowia zwierząt i zdrowotności roślin oraz dobrostanu zwierząt. 13 aktów prawnych wymienionych w załączniku II do rozporządzenia (UE) nr 1306/2013 tworzy trzon zasady wzajemnej zgodności. Wymogi związane z zasadą wzajemnej zgodności mogą być jednak różnie kształtowane przez poszczególne państwa członkowskie, w szczególności w przypadku dyrektyw, które w wyniku transpozycji do prawa krajowego mogą przewidywać środki dostosowane do poszczególnych obszarów. Szerszy zasięg wymogów zazieleniania wynika z faktu, że same przepisy dotyczące płatności bezpośrednich (art. 43 i nast. rozporządzenia (UE) nr 1307/2013) wprowadzają trzy określone praktyki środowiskowe, nakładając obowiązek ich jednolitego stosowania we wszystkich państwach członkowskich.

Zasada wzajemnej zgodności obowiązuje, co do zasady, wszystkich beneficjentów dopłat bezpośrednich, natomiast w przypadku płatności za zazielenienie prawodawca przewidział szereg wyjątków w kręgu rolników zobowiązanych do przestrzegania wymogów środowiskowych, o czym była mowa powyżej.

29 Na nowy okres programowania przepisy regulujące zasadę wzajemnej zgodności zostały umieszczone w rozporządzeniu Parlamentu Europejskiego i Rady (UE) nr 1306/2013 z dnia 17 grudnia 2013 r. w sprawie finansowania wspólnej polityki rolnej, zarządzania nią i monitorowania jej oraz uchylające rozporządzenia Rady (EWG) nr 352/78, (WE) nr 165/94, (WE) nr 2799/98, (WE) nr 814/2000, (WE) nr 1290/2005 i (WE) nr 485/2008 (Dz.Urz. UE L 347 z dnia 20 grudnia 2013 r., s. 549), zwanym rozporządzeniem horyzontalnym zawierającym przepisy wspólne dla całej WPR. 
W inny sposób ukształtowano w obu systemach rozłożenie ciężaru dowodu. Praktyki zazieleniania są warunkiem złożenia wniosku i posiadania roszczenia do otrzymania wsparcia. ${ }^{30}$ Do czasu wprowadzenia zazieleniania na etapie ubiegania się o płatności bezpośrednie rolnik nie musiał wykazać spełnienia wymogów związanych z ochroną środowiska naturalnego. Obecnie, już na etapie składania wniosku o dopłaty bezpośrednie rolnik, deklarując hektary kwalifikujące się do wsparcia, musi zgłosić obszary, na których będą stosowane trzy obowiązkowe praktyki rolnicze, co jest następnie weryfikowane $\mathrm{w}$ drodze kontroli administracyjnych przeprowadzanych przez państwa członkowskie i Komisję. Natomiast dochowanie zobowiązań wynikających z zasady wzajemnej zgodności sprawdzane jest już na etapie otrzymywania wsparcia, przez podmiot przeprowadzający kontrolę (państwo członkowskie lub Komisja), który, aby nałożyć na beneficjenta karę administracyjną, musi udowodnić niedochowanie określonych obowiązków związanych z ochroną środowiska. W niektórych przypadkach może zachodzić przecinanie się praktyk związanych z zasadą wzajemnej zgodności i zazielenianiem. Przykładowo rolnik nieprzestrzegający obowiązku utworzenia stref buforowych nałożonego przez wymogi zasady będzie podlegał karze administracyjnej w tym zakresie. Może on jednak w dalszym ciągu wywiązać się z obowiązku wydzielenia obszarów proekologicznych zgodnie $\mathrm{z}$ wymogiem zazieleniania. $\mathrm{Z}$ drugiej strony, strefy buforowe mogą zostać zaliczone przez rolnika do obszarów proekologicznych. ${ }^{31}$

Inaczej skonstruowany jest też system sankcji. W przypadku zasady wzajemnej zgodności wykrycie przez kompetentny organ niezgodności będzie skutkowało nałożeniem kary administracyjnej przez Komisję. Zgodnie z art. 96 ust. 2 rozporządzenia (UE) nr 1306/2013 rolnik nie przestrzegający wymogów wynikających z tej zasady, może zostać obciążony przez właściwy organ krajowy sankcją bezpośrednio wynikającą z przepisów prawa regulujących daną dziedzinę (przykładowo z zakresu bezpieczeństwa żywności), wymienionych w załączniku II do rozporządzenia (UE) nr 1306/2013, których przestrzegania owa zasada wymaga. Komisja ma jednak możliwość przeprowadzenia dodatkowej kontroli zarówno w gospodarstwie rolnika, jak i w krajowych urzędach dokonujących kontroli. ${ }^{32}$ Kontrole przeprowadzane (i ewentualne kary administracyjne) w ramach zasady wzajemnej zgodności dotyczą jednak jedynie 5\% gospodarstw rolnych uprawnionych do płatności bezpośrednich.

Niedochowanie przez rolnika obowiązków związanych z zazielenieniem będzie przesłanką nałożenia kary administracyjnej, która, w pierwszych dwóch latach stosowania płatności za zazielenienie, czyli w 2015 r. i 2016 r., nie przekrorbuch 2010 , s. 87. 
czy kwoty tej płatności. Począwszy od 2017 r. będą mogły być nakładane wyższe kary administracyjne na podstawie art. 77 ust. 6 rozporządzenia (UE) nr 1306/2013. W 2017 r. nie będą one mogły przekraczać $20 \%$ kwoty płatności za zazielenienie, w 2018 r. $25 \%$ tej kwoty. Zgodnie z art. 77 ust. 6 akapit trzeci rozporządzenia (UE) nr 1306/2013 kary muszą być proporcjonalne oraz zróżnicowane stosownie do dotkliwości, zasięgu, trwałości i powtarzalności stwierdzonych niezgodności. Oznacza to, że od 2017 r. kara będzie miała wpływ na kwotę innych płatności otrzymywanych przez rolnika. Pomimo że wymogi zazieleniania nie mają bezpośredniego zastosowania do jednolitej płatności obszarowej, tzn. nie warunkują jej otrzymania, to ich niedochowanie nie pozostanie bez znaczenia dla jej wysokości w kolejnych latach wypłaty płatności w ramach wsparcia bezpośredniego.

\section{Skuteczność środka}

W okresie programowania 2007-2013 pozytywne oddziaływanie zasady wzajemnej zgodności wykazywało pewne niedociągnięcia, wynikające głównie z braku jednolitych wymogów dla wszystkich państw członkowskich oraz sporadyczności kontroli administracyjnych. ${ }^{33}$ Zazielenienie ma wzmocnić element środowiskowy w ramach WPR, uzależniając podstawowy system wsparcia w rolnictwie od jednolitych dla wszystkich państw członkowskich wymogów. Jednak, jak wspomniano powyżej, obecna regulacja przewiduje szereg wyłączeń, a przykład Polski pokazuje, iż ze względu na wielkość gospodarstw rolnych znaczna ich część zostanie zwolniona $\mathrm{z}$ obowiązku stosowania praktyk zazielenienia. W konsekwencji do gospodarstw tych będą miały zastosowanie jedynie, a i to nie zawsze, wymogi zasady wzajemnej zgodności. Nałożenie na wszystkich rolników w Unii jednakowych obowiązków w zakresie ochrony środowiska jest jednak znaczącym osiągnięciem prawodawcy unijnego.

Należy poczekać na sprawozdania na temat zasadności włączenia do systemu dopłat bezpośrednich obowiązkowego komponentu ekologicznego oraz rozmiarów jego pozytywnego oddziaływania na środowisko naturalne. Prognozy dotyczą możliwego rozszerzenia zasięgu praktyk zazielenienia, ich zaostrzenia i zwiększenia ich udziału w kwocie wsparcia bezpośredniego w kolejnych okresach programowania. Może to oznaczać objęcie wymogami środowiskowymi większej niż 30\% pułapów krajowych. ${ }^{34} \mathrm{Z}$ punktu widzenia sankcji może to oznaczać bardziej dotkliwe niż obecnie zmniejszenie całkowitej kwoty płatności w przypadku niedochowania wymogów środowiskowych.

Szerzej na ten temat zob. A. Korycińska, Przyszłość cross-compliance w świetle dyskusji o systemie płatności bezpośrednich po 2013 r., http://www.fapa.org.pl/ 
THE GREENING PAYMENT IN THE NEW MODEL OF DIRECT PAYMENTS

Keywords: direct support, greening payment, cross-compliance principle

By means of Regulation (EU) No 1307/2013 of the European Parliament and of the Council, a new component, i.e. the greening payment, has been included into the Union direct support scheme rendering direct support conditional upon applying by farmers the compulsory agricultural practices beneficial for the climate and the environment. The legal nature of the greening payment and consequences of noncomplying with the set obligations are being analyzed. The new environmental conditionality of direct support is considered by referring to the existing system of the cross-compliance principle. The requirement of farmer's declaration on compliance with the environmental obligation already at the stage of application for payment should be seen as an important achievement on the path of setting a compulsory link between the common agricultural policy and the environmental policy of the Union; numerous exceptions from applying environmental practices might however weaken the system.

Bibliografia:

J. Bieluk, Charakter prawny płatności w systemie wsparcia bezpośredniego, [w:] Obrót gospodarczy w prawie rolnym, B. Jeżyńska (red.), Lublin 2009.

J. Bieluk, D. Łobos-Kotowska, Posiadanie gruntów rolnych jako warunek nabycia prawa do płatności bezpośrednich, Studia Iuridica Agraria 2010, t. VIII, s. 137.

G. Eckhardt, Die Reform der GAP 2013 - Zwischenbilanz und Ausblick, [w:] Norer, Holzer (red.), Agrarrecht. Jahrbuch 2010.

G. Holzer, Die neue „Ökoarchitektur” der GAP, w: Norer, Holzer (red.) Agrarrecht. Jahrbuch 2015.

A. Korycińska, Przyszłość cross-compliance w świetle dyskusji o systemie płatności bezpośrednich po 2013 r., http://www.fapa.org.pl/

J. Martinez, Das Greening der Gemeinsamen Agrarpolitik, „Natur und Recht” (2013) 35.

B. Mittermüller, Die Ökoprämie und ihre „eigentümliche” Rechtsnatur, [w:] Norer, Holzer (red.), Agrarrecht. Jahrbuch 2014.

B. Schima, Der Vorschlag der Kommission für eine neue Direktzahlungsverordnung, [w:] Norer, Holzer (red.) Agrarrecht. Jahrbuch 2012.

„System płatności bezpośrednich w latach 2015-2020” Warszawa, maj 2015, dostępny na stronie: www.minrol.pl 